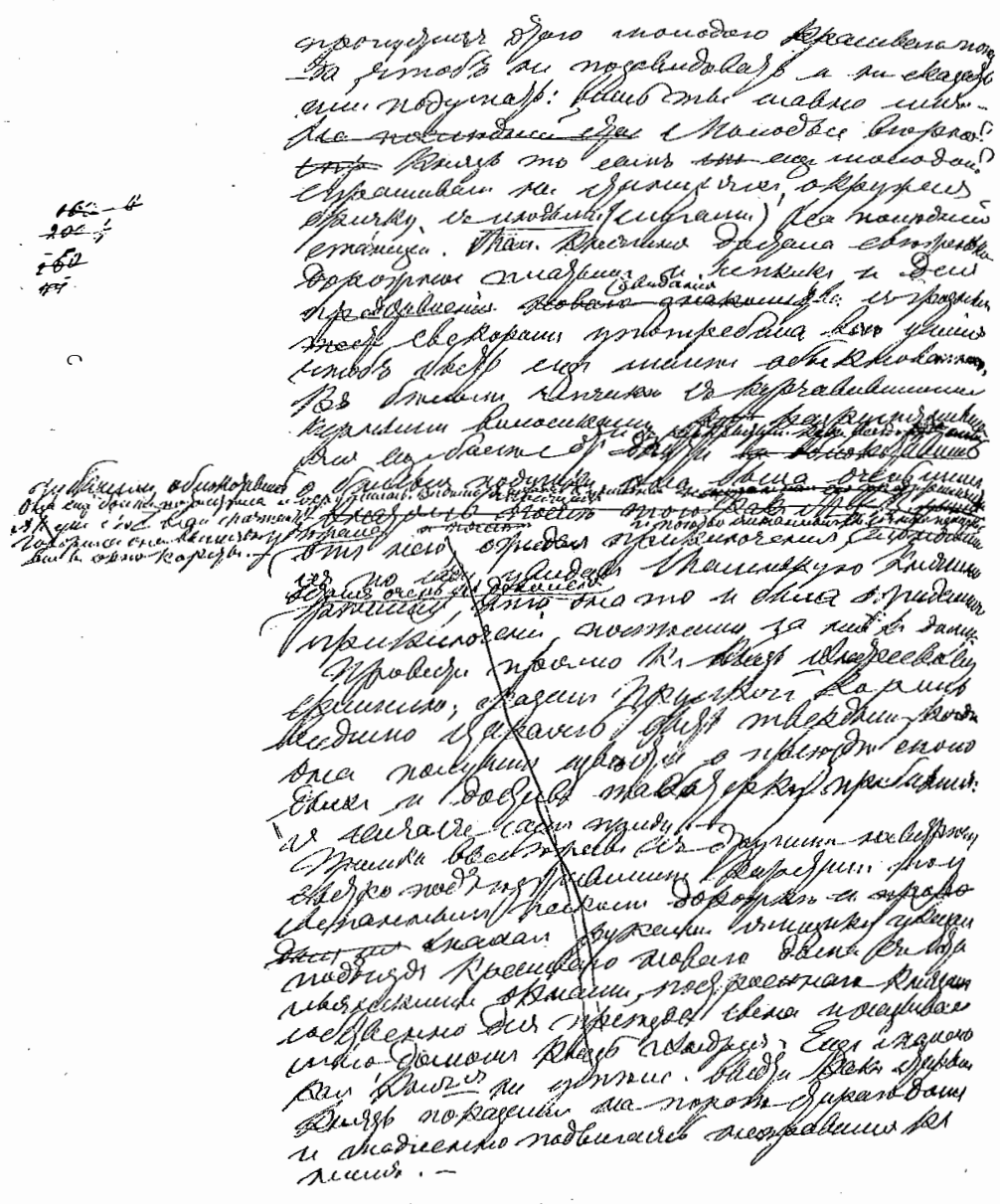

Fra Tolstojs første udkast til Krig og fred.

\section{VEJEN - STEDET}

\section{Ulla Ryum}

\section{1. kap. : - vinderen lober forbi}

Jeg har besluttet at nedskrive min egen historie. Mit liv har fundet sted, så alt, hvad jeg skriver herefter, er den roman, hvori jeg optrådte så mange år; fra kapitel til kapitel. Jeg er kun 12 år gammel og står ved vinduet for at se vinderen lobe forbi. Han er tre kvarter forsinket; men han er sikker vinder. Det ved jeg. Jeg elsker ham på billedet $\mathrm{i}$ avisen. $\mathrm{Nu}$ kommer han snart.

\section{2. kap. : - lyset bag gardinerne}

Alt begyndte den dag. Alt fandt sted som beskrevet i bogen: "Mit liv med verdens hurtigste mand". Farvefoto og skåneomslag. Dette er min egen historie om lyset bag vores gardiner; det var dette lys han så, og altid siden løb efter. "Så ved jeg hvor jeg bor," sagde han i forbifarten. Når jeg hørte de sidste ord — jeg bor — var de første så ved jeg hvor — forlængst forbisagt, elskede!

\section{3. kap.: - igen alene}

Så er jeg kun 21 år gammel. Vi blev gift for fire år siden imorgen. Den første dreng var dødfødt. Så blev det tvillingepiger. Som holdt de hinanden fast $i$ livet, lå de altid hånd $i$ hånd. Jeg ser dem vinke til deres far i hans forbifart. Dengang husker jeg at jeg følte mig alene, selvom jeg jo havde børnene og lyset bag vores gardiner krævede 
også at jeg var der, når han kom forbi.

\section{4. kap.: - tonen gentages}

Min familie hjalp mig og mor har set det gang på gang. Både mine to ældre søstre og kusinen fra fars side. Altid det samme. Sidder og venter hen i vejret. Men min mand kommer dog jævnligt forbi på en af sine ruter i et af sine løb. Selvfølgelig er jeg tålmodig. Vi talte sammen p.g.a. et uheld, så han havde tid til overs, og han bad mig altid huske, at jeg var lyset i hans liv, elskede!

\section{5. kap.: - lyset er slukket for natten}

Så er jeg kun 31 år gammel. P.g.a. uheldet fik vi en efternøler. Vores lille dreng. Tvillingerne elsker deres lille broder, som på dette tidspunkt allerede er næsten syv år gammel. Vi er alle så glade også min mand, som stadig vinder af og til. For mig er natten en gave. De sover alle, og tænder jeg lys, er det som at kalde på det første billede jeg så $\mathrm{i}$ avisen dengang, min elskede!

\section{6. kap.: - en anden beretning}

Det har været krig længe. Ikke i vores land, men vi fører krigen mod mennesker vi aldrig har mødt. Min mand meldte sig som rådgiver og instruktør for vores unge drenge. Hvad med de andres unge drenge, spurgte jeg, uden at tænke nærmere over det. Det var første gang min mand slog mig. Heldigvis var ingen af børnene hjemme. Glem aldrig hvem jeg er, og husk at du er mit lys. Dette løb er det længste jeg endnu har deltaget $\mathrm{i}$; så gik han og jeg så ham først på en videofilm tre år senere. Hils min kone og mine dejlige unger, sagde han, og sig til dem at jeg har det ok. Han var en blandt andre som var i fangenskab. Det havde vi nu vidst længe. Så bliver han ikke helt i kamp, sagde vores søn. Nej og hvad så, spurgte tvillingedøtrene. De er fredsaktivister.

\section{7. kap.: - ventesalene lukkes aldrig}

Så er jeg kun 41 år gammel. Jeg føler mig yngre. Han kom hjem igår efter middagen. De ringede fra aviserne og ville fotografere ham. Fordi han havde udstået fangenskabet hos umenneskerne. Var de det, tænkte jeg, men ikke højt. Han havde slået mig een gang. Jeg kan ikke længere få øje på mig selv som noget lys. Underligt at være hjemme igen, sagde han og lod sig fotografere ved vinduet hvorfra jeg så ham den første gang. Er det deres kone, var der nogen som spurgte, ska vi ikke tage et par med hende også - selvfølgelig, svarede han - dette vindue betyder en masse for os - her så hun mig første gang. Gennem gardinet, var der en som spurgte. Rigtigt, sva- rede han og trak mig ned til sig. På billederne virkede det kærligt nok. Hvad venter vi på, spurgte han så.

8. kap. : - på rejse hertil

De følgende år følte jeg mig stadig yngre og yngre, indtil jeg pludseligt mistede mit arbejde. Blomsterbutikkens ejer døde. Han var min fars bedste ven. De havde været meget for hinanden efter min mors sygdom og hendes død. Alle er snart døde, sagde min far. Jeg savner mine daglige blomster. Men børnene klarer sig selv. Nu er jeg 47 år gammel og ingen kender mig. Min mands tidligere liv som vinder og hans senere som overlevende fange skal filmatiseres. Børnene og jeg skal bare medvirke i mindre roller. Vi skal bare tage det roligt, for vores replikker virker naturlige i sammenhængen, siger han. Instruktøren har fået nogle billeder af os, for at komme rigtigt ind på livet af os. Jeg har i et par dage følt det som om jeg var på en rejse uden at vide hvorhen.

\section{9. kap.: - den sene ankomst}

Det er sandt at jeg er på rejse. I begyndelsen troede jeg det var en slags overanstrengelse, at jeg måske var syg. Men nu forstår jeg at det er en gave. Jeg rejser hver dag ud gennem mit gardin og oplever landskaber, som jeg ikke vidste fandtes. Taler med andre mennesker, som har det på samme måde, og sammen med dem forstår jeg alt det jeg ikke kunne fatte før. Mine børn ved ingenting. Det ville sikkert heller ikke interessere dem at vide noget andet om mig end det de altid har vidst. Min mand har fundet en ung kvinde. Eller sandsynligvis er det hende som har fundet ham. Han ved ikke at jeg ved det. Hun kommer af og til og snakker med mig. Det er ikke let for hende, men hvad kan jeg gøre for at hjælpe hende? Den mand hun kender er ikke længere ham jeg kendte. Han overnatter en sjælden gang i sengen ved siden af min. Sover som et plaget menneske, alt for tungt og vågner grå af gammelt nag. Jeg ser det uden angst. Var elsket.

\section{0. kap. : - vinderens sidste løb}

Min mands eneste søster vil ikke længere betale for deres forældre gravsted. Min mand er oprørt. Han vil hvile hos dem engang, siger han. Vil have at jeg skal tage mig sammen og hjælpe ham. Det vedkommer ikke mig. Tvillingerne venter begge to børn uden fædre med fem dages mellemrum. Vores søn har giftet sig med en fremmedartet. Hans far siger at han ikke længere er hans far. Det vedkommer heller ikke mig. Hun er sangerinde og de er lykkelige. Børnene kommer her når han er hos den anden. Hun og jeg er gode venner 
og forsøger at holde ham ud. Han virker allerede ældet. Det er jeg muligvis også, selvom jeg ikke føler det. Ville gerne glæde ham. Ville gerne være et lys igen, et lys han kunne genkende. Men det kan han ikke, for jeg er mig selv - elskede. Jeg findes som mig selv. Utænkeligt, siger han. En helt ukendt kan ikke genkendes. Hun har hængt billeder af ham op på alle væggene i sin lille lejlighed. Han føler sig hjemme der.

\section{1. kap. : - en tredie beretning}

Hun fortalte ved en senere lejlighed at han ville have alle billederne af sig selv med i kisten. Det lykkedes for hende at overtale bedemanden, fortalte hun med sagte stemme, men nu ville hun bede mig om et enkelt billede af ham. Der var et særligt et, som hun altid havde holdt så meget af. Om hun måtte få det. Det var det billede som havde drevet hende til at opsøge ham, selvom det var taget længe før hun var blevet født. Han hunne have været hendes far; det havde de ofte moret sig over. I det cafeteria, hvor hun sad ved kassen havde de et stort billede af ham lige netop som han kastede sig ind over målstregen. Det havde hun pludseligt fået det så dårligt med så nu var det flyttet. Det havde bare været for meget, men det andet billede var blevet så vigtigt for hende. Hun vidste godt at det var det samme billede som jeg var faldet for dengang før hun var født. Det havde han snakket om hver eneste aften. Ja.

\section{2. kap. : - daggry}

Venstresengen er omsider blevet flyttet. Gulvet under den er et fremmed landskab. I drømme har han kradset linoleum og tæppe op i bølgende figurer. Hvem kunne ane at han ville så meget med sit liv. I alle årene, $\mathrm{i}$ alle nætterne. Hele familien og hende har fribilletter til filmen om hans liv. Hun syntes vi alle gjorde det godt og helt naturtro, nu hvor hun kendte os så godt.

\section{3. kap.: - de glemte gaver}

Nu er jeg kun 70 år gammel og alle i familien var med på dagen. De må være dejligt at se tilbage på sådan et liv. Han lignede faktisk skuespilleren som er ham nu, siger de hver gang vi ses.

\section{4. kap. : - sangene først}

Der er en sang jeg holder meget af og synger mens jeg rejser. Et sted siger den noget lignende som: sangene først og stem dit sind. Rejsens lyde trænger ud gennem min mund bag mit gardin.

\section{5. kap. : - bagerst $i$ haven}

Igår var jeg nede bagerst $\mathrm{i}$ haven, hvor mine ting altid lå før $\mathrm{i}$ tiden Jeg fandt det hele, som den eftermiddag, da jeg forlod det og ved et tilfælde så hans billede i avisen - dit, ja.

\section{6. kap. : - hen under middag}

Vinderen løber her forbi, råbte mine to ældre søstre og satte papillotter i deres hår. Det gør han altid, svarede min mor, vi bor på ruten. Lyden af et tog, som kører, trænger ud af min mund.

\section{7. kap. : - på billedet}

Idag bliver billedet væk. Forårssolen æder din skygge, elskede. Alle vil komme og vende sig vinkende. De ankomne modtages, ingen mangler, vi kender hinanden fra før. Rejsens lyde aftager. Ja.

\section{8. kap.: - efterladte søges}

$\mathrm{Nu}$ er jeg kun

SLUT

Forklarende noter:

Filmen kan endnu ses, men alle eksisterende kopier er meget slidte.

Bogen Mit liv med verdens hurtigste mand kan sikkert findes nedsat med lidt held.

Efterskrift:

Jeg besluttede at nedskrive min egen historie. Mit liv har fundet sted, så alt hvad jeg har skrevet her er den roman, hvori jeg optræder gennem mange år og over 18 kapitler. Ja. 